Proc. Estonian Acad. Sci. Geol., 2005, 54, 3, 145-152

\title{
Height of the turbulent gas flow and transport distance of glassy spherules on the example of the Kaali impact, Estonia
}

\author{
Anto Raukas ${ }^{\mathrm{a}}$ and Kustav-Olimar Laigna ${ }^{\mathrm{b}}$ \\ a Institute of Geology at Tallinn University of Technology, Estonia pst. 7, 10143 Tallinn, Estonia; \\ raukas@gi.ee \\ ${ }^{\mathrm{b}}$ OÜ Teadusloome, Tartu mnt. 70-18, 10144 Tallinn, Estonia
}

Received 21 December 2004, in revised form 10 February 2005

\begin{abstract}
Impact ballistics of the Kaali impact group has been considered by a number of authors giving extremely different interpretations. The exact time of the impact is also debatable, but according to direct dates the age of the craters is at least 4000 years. Spherule studies in the mires of the islands of Saaremaa and Hiiumaa show that the impact took place some 7600 years ago. As the more or less vertical gas stream could have reached a height of $6.8-7.9 \mathrm{~km}$, the small glassy particles, often hollow inside, were easily transported over long distances.
\end{abstract}

Key words: emitted gas flow, Kaali impact, crater age, spherule transportation.

\section{INTRODUCTION}

At least nine impact craters are located at Kaali $\left(58^{\circ} 24^{\prime} \mathrm{N}, 22^{\circ} 40^{\prime} \mathrm{E}\right), 19 \mathrm{~km}$ $\mathrm{NE}$ of the town of Kuressaare on Saaremaa Island. The main crater has a diameter of $105-110 \mathrm{~m}$ and is about $22 \mathrm{~m}$ deep. The energy needed for the formation of the main crater is traditionally estimated as $4 \times 10^{19} \mathrm{ergs}$ (Koval 1974). Many authors have considered impact ballistics of the Kaali group and obtained extremely different results (see a review in Czegka \& Tiirmaa 1998). At the time of the impact, the meteorite weighed probably $20-80 \mathrm{t}$ and its velocity was $10-20 \mathrm{~km} / \mathrm{s}$ (Bronshten \& Stanyukovich 1963). According to Pokrovski (1963), the Kaali meteorite was about $4.8 \mathrm{~m}$ in diameter; its mass was $450 \mathrm{t}$ and impact velocity $21 \mathrm{~km} / \mathrm{s}$. Koval (1974) suggested that the mass of the meteorite, which formed the main crater, was 40-50 t and the impact velocity about $13 \mathrm{~km} / \mathrm{s}$.

The exact time of this event is also debatable. From simultaneous ${ }^{14} \mathrm{C}$ and palynological studies Saarse et al. (1992) concluded that the ${ }^{14} \mathrm{C}$ age of bottom sediments of Lake Kaali in the main crater is at least $3390 \pm 35$ years BP (sample 
Tln-1353) and that the meteorite fell about 4000 years BP. AMS dating of terrestrial macrofossils from these sediment layers places the age of the impact at 1690-1510 BC or some 3500-3700 years BP (Veski et al. 2004). Rasmussen et al. (2000) found a distinct Ir-enriched layer in Piila mire about $10 \mathrm{~km}$ northwest of the craters (Fig. 1). Radiocarbon dating of the layer produced the age of $2305 \pm 20{ }^{14} \mathrm{C}$ years BP (the calibrated date is $400-370$ years BC at $\pm 1 \sigma$ ). The above-named authors believed that it was the time of the impact. After dendrochronological calibration, Veski et al. (2001) changed the age of enrichment $\left(2560 \pm 85{ }^{14} \mathrm{C}\right.$ years BP) and the impact to about $800-400 \mathrm{BC}$. The last two conclusions must be wrong, because according to direct dates from the bottom of Lake Kaali, the age of the impact is undoubtedly more than 3500 years (Raukas et al. 2003). Already peat from a depth of $1.18-1.25 \mathrm{~m}$ gave the ${ }^{14} \mathrm{C}$ age of $2958 \pm 51 \mathrm{BP}$ (Tln-2576), which after dendrochronological calibration is some 3260-3050 years BP. Heavy pollution is excluded, because a tree trunk from a nearby excavation yielded the age of $2673 \pm 47{ }^{14} \mathrm{C}$ years BP $(\mathrm{T} \ln -2573)$. We would

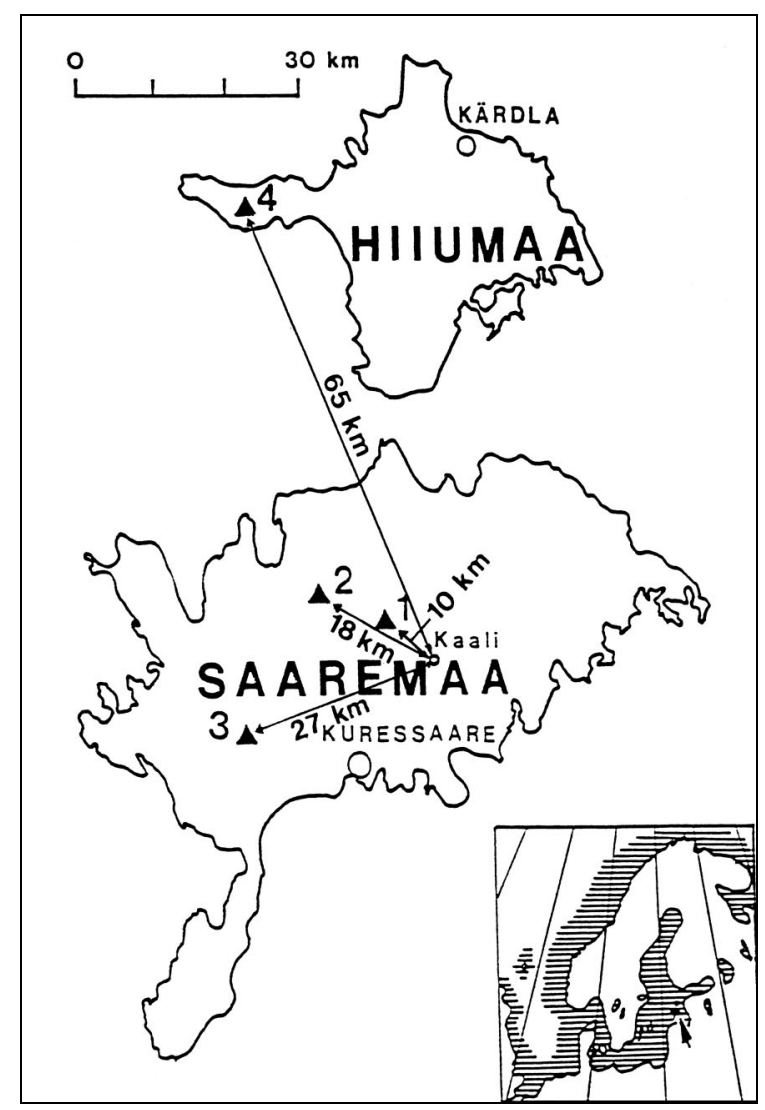

Fig. 1. Location map of Kaali craters and the distances of investigated mires from the crater field. Mires: 1, Piila; 2, Peli; 3, Pitkasoo; 4, Kõivasoo. 
like to underline that our excavations were far from the bottommost part of the main crater (Raukas et al. 2003). As sedimentation in the crater started long after the event, indirect methods are needed to estimate the real age of the impact.

During the studies of 1994 we found a high concentration of glassy spherules (microimpactites) in the Lower Atlantic peat of Piila mire $10 \mathrm{~km}$ northwest of the Kaali craters (Fig. 2), dated at $7586 \pm 67$ years BP with the ${ }^{14} \mathrm{C}$ method (Raukas et al. 1995). In the next years, spherules of the same age were discovered in Peli mire, ca $18 \mathrm{~km}$ northwest of the Kaali craters and in Kõivasoo mire on Hiiumaa Island ca $65 \mathrm{~km}$ from the craters (Fig. 1). In 1996, coeval spherules were detected also in Pitkasoo mire in the western part of Saaremaa, about $27 \mathrm{~km}$ southwest of Kaali (Raukas 1997).

Since in all the above-mentioned mires silicate spherules were detected only in one layer, we proposed a new precise correlation method for Holocene sequences, based on these microimpactites. Using this method, we suggested that the age of the Kaali impact is $7600 \pm 50$ years BP (Raukas 2000).

Our main tasks have been to prove the impact origin of the spherules found (Raukas 1997; Marini et al. 2004) and to explain the possibility of the distribution of spherules over the territory of several hundred square kilometres. There is no doubt that the Kaali main crater was generated by a mighty explosion (Raukas \& Laigna 2003), which destroyed the surroundings nearby and formed a crater mound with uplifted dolostone blocks (Fig. 3). Heated gases were directed upwards to a

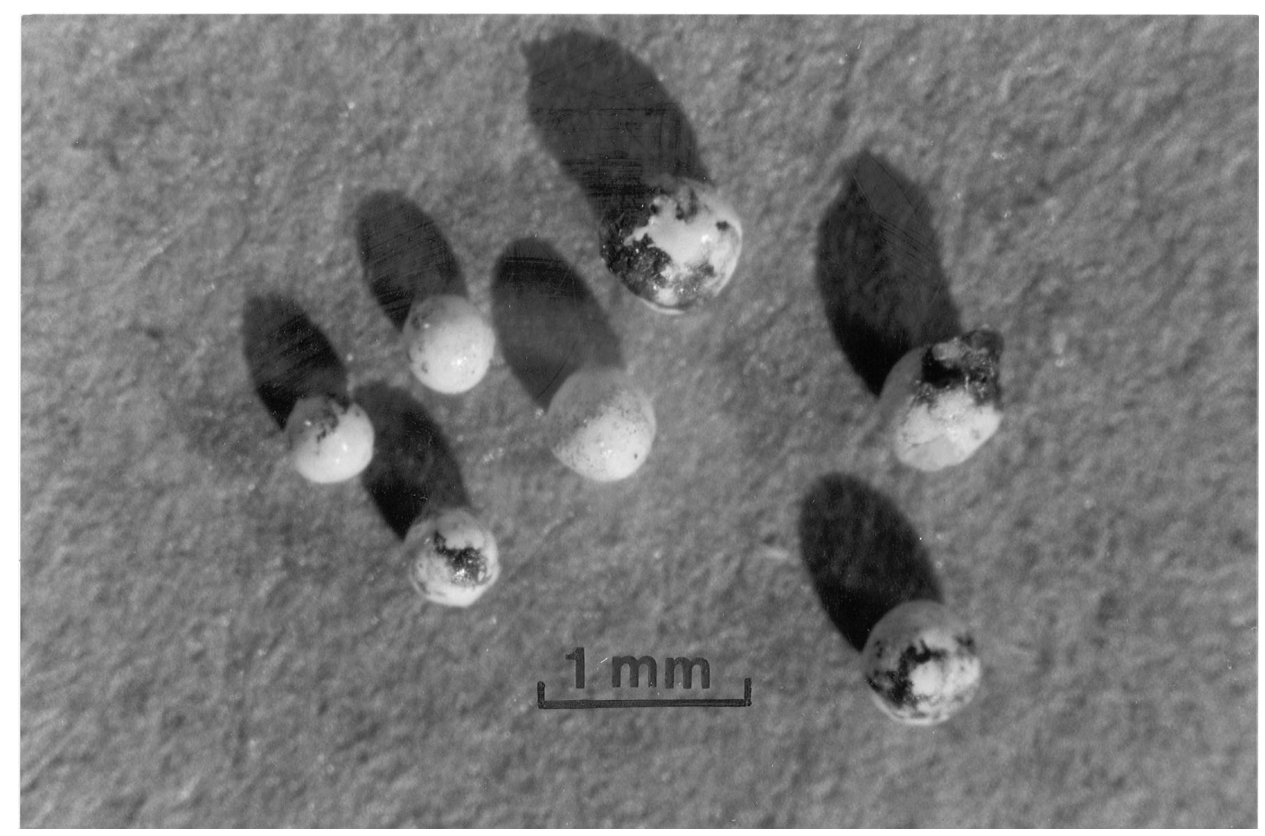

Fig. 2. Typical spherules from Piila mire (about $10 \mathrm{~km} \mathrm{NW}$ of the Kaali crater area, Fig. 1). Photo by G. Baranov. 


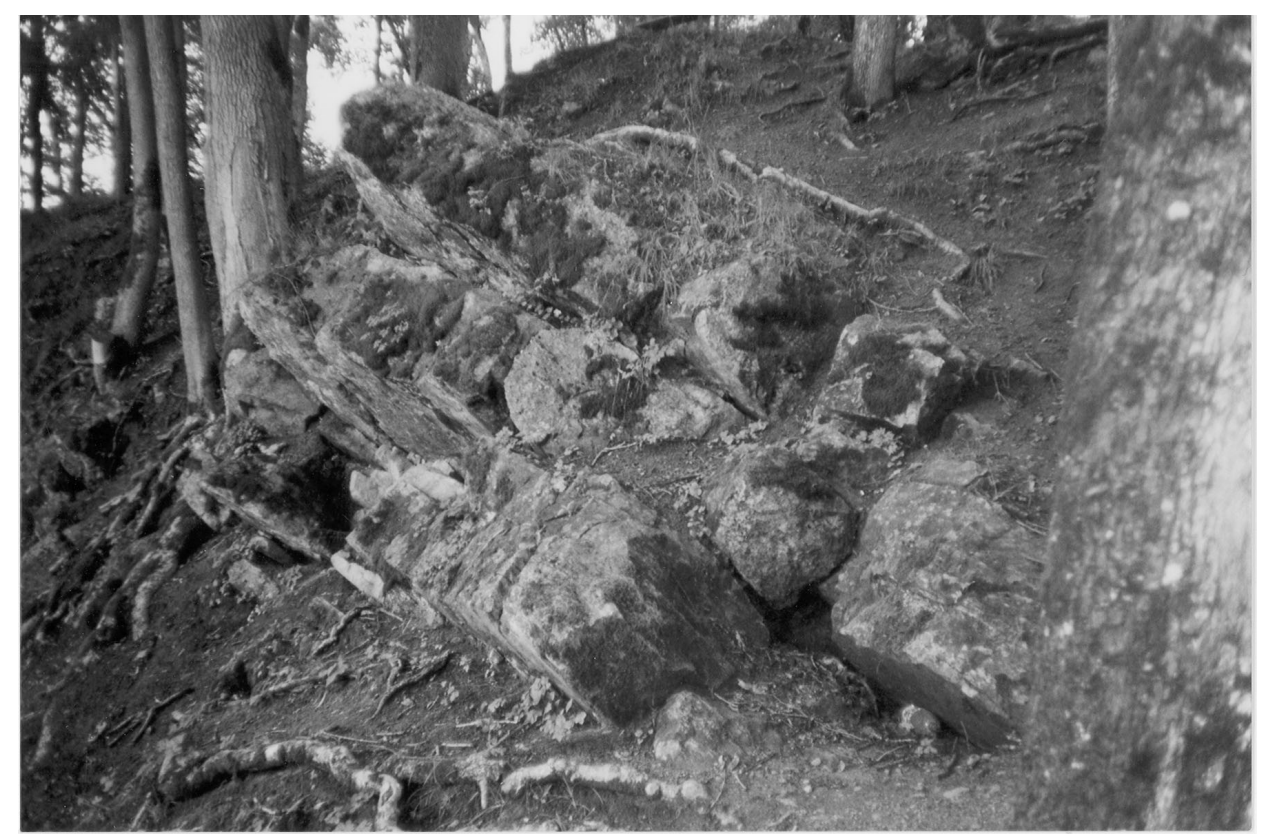

Fig. 3. Some $60 \%$ of the crater-forming energy in the main crater was transferred to the formation of the crater and its mound, as well as to the damage of the surrounding rocks. Uplifted dolostone blocks on the crater wall. Photo by R. Tiirmaa.

height of several kilometres and, therefore, complete melted spherules (sometimes hollow internally), originating from the impact of crater-producing meteorite, could be distributed over a vast area, and easily during heavy wind.

\section{CALCULATION OF THE HEIGHT OF THE EMITTED GAS FLOW}

Crater formation by a hypervelocity impact is a relatively well studied and mathematically modelled process (Melosh 1989). For comparison, data on artificial explosions could be taken. During a meteoritic impact, most of the impactor's genetic energy is transferred to the target rocks, giving rise to a short pulse of high pressure and to particle motions and ejection (Deutsch \& Schärer 1994). According to our calculations, some $60 \%$ of the crater forming energy (ca $1.85 \times 10^{11} \mathrm{~J}$ ) was transferred to the formation of the crater and mound, as well as to the deformation of the surrounding rocks consisting of Upper Silurian dolostones of the Paadla Regional Stage with a thin cover of till of the last, Weichselian glaciation (Raukas \& Laigna 2003). According to seismic and electrometric measurements, the area of the shattered rocks surpasses the dimensions of the crater at least twice, covering about $0.1 \mathrm{~km}^{2}$ (Aaloe et al. 1976). 
If considering the main crater as a segment of a sphere with a radius $R=55 \mathrm{~m}$ and height $h=18 \mathrm{~m}$, the volume of the main crater would be $81623 \mathrm{~m}^{3}$. The calculated amount of the material ejected from the crater is practically the same, $81291 \mathrm{~m}^{3}$. A hypervelocity three-dimensional gas flow ejected from the crater had a high temperature gradient with respect to the surrounding environment. The height of the velocity turbulent flow should be treated according to the equivalent heat transmission theory. Taking the initial parameters of the gas flow as follows: initial temperature $2500-3000 \mathrm{~K}$, initial speed 6-9 km/s, initial density $1.02 \mathrm{~kg} / \mathrm{m}^{3}$, initial pressure $5.6 \times 10^{4} \mathrm{~atm}$, initial diameter $4.8 \mathrm{~m}$, and solving the corresponding equation system (Vulis \& Yarin 1978), we obtain 6.8-7.9 km for the height of the gas flow. According to our calculations, the temperatures of the gas flow and surrounding air are equal at that height.

The rate of the turbulent flow at a point of the cross-cut may be determined from the equation

$$
u / u_{m}=\sqrt{\frac{\rho_{m}}{\rho_{0}}} \cdot \frac{F^{\prime}(\varphi)}{\varphi}
$$

where the corresponding temperature gradient is

$$
\frac{\Delta T}{\Delta T_{0 m}}=\frac{\frac{\rho_{m}}{\rho}+\frac{\kappa-1}{2} M_{m}^{2} \frac{u^{2}}{u_{m}^{2}}-\frac{\rho_{m}}{\rho_{\infty}}}{1+\frac{\kappa-1}{2} M_{m}^{2}-\frac{\rho_{m}}{\rho_{\infty}}} .
$$

Here $u_{m}$ is the rate of gas movement and $\rho_{m}$ gas density on the crosscut axis of the gas stream under consideration; $\rho_{0}$ is initial gas density; $F^{\prime}(\varphi)=\left(u / u_{m}\right)_{\rho=\text { const }} ; \frac{\Delta T}{\Delta T_{0 m}}=\frac{\Delta T_{m}}{\left(\Delta T_{0}\right)_{\rho=\text { const }}} \cdot\left(\frac{\rho_{0}}{\rho_{m}}\right)^{1 / 2} ; \Delta T$ is temperature gradient; $\kappa=c_{p} / c_{v}$ is adiabatic index; $c_{p}, c_{v}$ are specific heat of gas with constant pressure and volume; $M_{m}$ is Mach's number on stream axis; $\rho_{\infty}$ is gas density outside the gas stream.

In case of gas stream dynamic task the equation of three-dimensional equivalent heat transmission may be expressed as follows:

$$
\frac{\partial \rho u^{2}}{\partial \xi}=\frac{\partial^{2} \rho u^{2}}{\partial \eta^{2}}+\frac{\partial^{2} \rho u^{2}}{\partial \zeta^{2}} \quad(\xi=\xi(x), \eta=y, \zeta=z)
$$


where the boundary conditions are

$$
\rho u^{2}=F_{0}(\mu, \zeta) \text { if } \xi=0, \rho u^{2} \rightarrow 0 \text { if } \eta \rightarrow \infty, \xi \rightarrow \infty
$$

Equation $\left(3^{\prime}\right)$ is not closed. The maximum height of the gas stream can be found using the sources summation method

$$
\frac{\rho u^{2}}{\left(\rho u^{2}\right)_{0}}=\frac{1}{4 \pi \xi} \int_{-b-c}^{+b+c} \int_{0}^{+c} F_{0}(y, z) \exp \left[-\frac{(y-\eta)^{2}+(z-\zeta)^{2}}{4 \xi}\right] \mathrm{d} \eta \mathrm{d} \zeta .
$$

By giving the initial cross-cut a rectangular shape, Eq. (4) can be expressed in the following way:

$$
\frac{\rho u^{2}}{\left(\rho u^{2}\right)_{0}}=\frac{1}{4}\left[\operatorname{erf}\left(\frac{y+b}{2 \sqrt{\xi}}\right)-\operatorname{erf}\left(\frac{y-b}{2 \sqrt{\xi}}\right)\right]\left[\operatorname{erf}\left(\frac{z+c}{2 \sqrt{\xi}}\right)-\operatorname{erf}\left(\frac{z-c}{2 \sqrt{\xi}}\right)\right],
$$

where $\operatorname{erf}(\psi)=\frac{2}{\sqrt{\pi}} \int_{0}^{\psi} e^{-t^{2}} \mathrm{~d} t=\int{ }^{(y+b) / 2 \sqrt{\xi}} e^{-t^{2}} \mathrm{~d} t ; \psi=\frac{y^{ \pm} \pm b}{2 \sqrt{\xi}}, \psi=\frac{z^{ \pm} \pm c}{2 \sqrt{\xi}}$

The complex $\left(\rho u^{2}\right)_{m} /\left(\rho u^{2}\right)_{0}$ can be expressed as

$$
\frac{\left(\rho u^{2}\right)_{m}}{\left(\rho u^{2}\right)_{0}}=\operatorname{erf}\left(\frac{b}{2 \sqrt{\xi}}\right) \operatorname{erf}\left(\frac{c}{2 \sqrt{\xi}}\right) .
$$

Here $\operatorname{erf}(\psi)=\frac{2}{\pi} \int_{0}^{x} e^{-t^{2}} \mathrm{~d} t ; a, b$ are sides of the rectangle (in calculations $a=b$ ).

Analogously to Eqs. (3)-(6), the gas stream temperature task may be presented in the form

$$
\frac{\partial}{\partial \xi}\left(\rho u c_{p} \Delta T\right)=\frac{\partial^{2}}{\partial \eta^{2}}\left(\rho u c_{p} \Delta T\right)+\frac{\partial^{2}}{\partial \zeta}\left(\rho u c_{p} \Delta T\right)
$$

Solving the above equations, we obtained, as mentioned before, $6.8-7.9 \mathrm{~km}$ for the gas stream maximum height, if the speed of the meteorite at the moment of the impact was $16 \mathrm{~km} / \mathrm{s}$. Falling down from the height of the surroundings, explosion-generated microimpactite matter could have covered a large area, which has been confirmed by our studies (Raukas 2000).

As we do not know the exact velocity and other ballistic parameters of the Kaali meteorite, our results are preliminary. However, the main idea that small glassy particles could be transported over long distances is not debatable. 


\section{CONCLUSIONS}

The gas streams ejected into the atmosphere as a result of the Kaali impact were three-dimensional turbulent flows. In respect of the surrounding environment, these may be treated as non-isothermal flows with a high temperature gradient. The results of the study of small impact craters and relevant laboratory experiments (e.g. Melosh 1989) allowed us, after mathematical calculations based on published data about impact ballistics of the Kaali group, to conclude that the heated gas stream reached a height of $6.8-7.9 \mathrm{~km}$ and the distribution of small (mainly less than $1 \mathrm{~mm}$, Fig. 2) glassy silicate microimpactites over a vast area was a normal process. Based on direct datings, the age of the Kaali impact is undoubtedly older than 3500 years BP and, according to our spherule studies, can be placed to some 7600 years BP. The wall of the main crater is divided into several blocks and intersected with a dense system of cracks resembling typical karst hollows. Therefore, the water table in the newly-formed hollow was seasonally and annually very unstable and bottom sediments started to accumulate in Lake Kaali long after the time of the impact. This means that the real age of the impact can only be determined using indirect dating methods. Investigation of bottom deposits of the lake can give only the minimal age of the impact, which is some 4000 years BP.

\section{ACKNOWLEDGEMENTS}

The research was supported by State Target Funding Project 0331759s01. We are grateful to Helle Kukk who typed and made the preliminary linguistic revision of the manuscript, to Reet Tiirmaa and Gennadi Baranov for photos and Rein Vaher for drawing Fig. 1. Our special thanks go to the referees of the paper Wojciech Stankowski and Kalle Suuroja for their valuable comments.

\section{REFERENCES}

Aaloe, A., Dabizha, A., Karnaukh, B. \& Starodubtsev, V. 1976. Geophysical investigations of Kaali crater. Eesti NSV Tead. Akad. Toim. Geol., 25, 58-63 (in Russian).

Bronshten, V. \& Stanyukovich, K. 1963. On the fall of the Kaali meteorite. Eesti NSV Tead. Akad. Geol. Inst. Uurimused, 11, 73-83 (in Russian).

Czegka, W. \& Tiirmaa, R. 1998. Das holozäne Meteoritenkraterfeld von Kaali auf Saaremaa (Ösel), Estland. Aufschluss (Heidelberg), 49, 233-252.

Deutsch, A. \& Schärer, U. 1994. Dating terrestrial impact events. Meteoritics, 29, 301-322.

Koval, V. I. 1974. About the mass and composition of the Kaali meteorite. Astron. Vestnik, 8, 169176 (in Russian).

Marini, F., Raukas, A. \& Tiirmaa, R. 2004. Magnetic fines from the Kaali impact-site (Holocene, Estonia): preliminary SEM investigation. Geochem. J., 38, 107-120.

Melosh, H. J. 1989. Impact Cratering. A Geologic Progress. Oxford University Press, New York.

Pokrovski, G. 1963. Computation of the parameters of a meteorite according to the crater caused by its fall. ENSV Tead. Akad. Geol. Inst. Uurimused, 11, 61-71 (in Russian). 
Rasmussen, L. K., Aaby, B. \& Gwozdz, R. 2000. The age of the Kaalijärv meteorite craters. Meteor. \& Planet. Sci., 35, 1067-1071.

Raukas, A. 1997. An attempt to use microimpactites in establishing the age of impact events on the example of the Kaali crater field (Estonia). Sphaerula, 1, 32-41.

Raukas, A. 2000. Investigation of impact spherules - a new promising method for the correlation of Quaternary deposits. Quat. Intern., 68-71, 241-242.

Raukas, A. \& Laigna, K.-O. 2003. Kaali meteoriidiplahvatuse purustusjõust. In Eesti geoloogide neljas ülemaailmne kokkutulek. Eesti geoloogid uue sajandi künnisel. Konverentsi materjalid ja ekskursioonijuht (Plado, J. \& Puura, I., eds.), pp. 74-76. Eesti Geoloogia Selts, Tartu Ülikooli geoloogia instituut, Tartu.

Raukas, A., Pirrus, R., Rajamäe, R. \& Tiirmaa, R. 1995. On the age of the meteorite craters at Kaali (Saaremaa Island, Estonia). Proc. Estonian Acad. Sci. Geol., 44, 177-183.

Raukas, A., Laigna, K. \& Moora, T. 2003. Olematu looduskatastroof Saaremaal 800-400 aastat enne Kristust. Eesti Loodus, 1, 12-15.

Saarse, L., Rajamäe, R., Heinsalu, A. \& Vassiljev, J. 1992. The biostratigraphy of sediments deposited in the Lake Kaali meteorite impact structure, Saaremaa Island, Estonia. Bull. Geol. Soc. Finland, 63, 129-139.

Veski, S., Heinsalu, A., Kirsimäe, K., Poska, A. \& Saarse, L. 2001. Ecological catastrophe in connection with the impact of the Kaali meteorite about 800-400 B.C. on Saaremaa Island, Estonia. Meteor. \& Planet. Sci., 36, 1367-1375.

Veski, S., Heinsalu, A., Lang, V., Kestlane, Ü. \& Possnert, G. 2004. The age of the Kaali meteorite craters and the effect of the impact on the environment and man: evidence from inside the Kaali craters, island of Saaremaa, Estonia. Veget. Hist. Archaeobot., 13, 197-206.

Vulis, L. A. \& Yarin, L. P. 1978. Aerodynamika fakelya. Energiya, Leningrad (in Russian).

\section{Turbulentse gaasijoa kõrgusarvutus ja klaasjate sfäärulite kandumiskaugus Kaali meteoriidiplahvatuse näitel}

\section{Anto Raukas ja Kustav-Olimar Laigna}

Osa Kaali meteoriidi plahvatusenergiast kulus kraatrisüvendi ja kraatrivalli kujundamiseks, osa (ligikaudu 40\%) suundus ülehelikiirusega gaasijoana vertikaalselt üles. Sellel kolmemõõtmelisel turbulentsel gaasijoal oli ümbritseva keskkonna suhtes kõrge temperatuurigradient. Lugedes joa algtemperatuuriks $2500-3000 \mathrm{~K}$, algkiiruseks $6-9 \mathrm{~km} / \mathrm{s}$, algtiheduseks $1,02 \mathrm{~kg} / \mathrm{m}^{3}$, algrõhuks $5,6 \times 10^{4} \mathrm{~atm}$ ja algdiameetriks $4,8 \mathrm{~m}$ ning lahendades vastava võrrandisüsteemi, saame kuuma joa õhkupaiskumise kõrguseks 6,8-7,9 km. Sellel kõrgusel omandas juga välisõhu temperatuuri. Juga kandis atmosfääri rohkesti kõrgel temperatuuril klaasjaks sulanud peent mikroimpaktiitset materjali, mis hajus väga ulatuslikul alal, kandudes näiteks Hiiumaalegi (joon 1). Saaremaa ja Hiiumaa sfääruleid sisaldavate soosetete vanuseks on ligikaudu 7600 aastat, mis on ka Kaali kraatrite kõige tõenäolisemaks vanuseks. Otseste kraatriuuringutega ei ole plahvatuse aega võimalik täpselt määrata. Sel teel saadud kraatrite vanuseks on vähemalt 4000 aastat. 